\title{
Reliability Analysis of a Pre-Stressed Concrete Beam in Flexural Failure
}

\author{
Hadiza Ali ${ }^{1}$, Abubakar I. ${ }^{2}$, Ejeh S.P. ${ }^{3}$ \\ ${ }^{1}$ Department of Civil Engineering, Kaduna Polytechnic, Kaduna \\ 2,3 Department of civil Engineering, Ahmadu Bello University Zaria \\ Nigeria
}

\begin{abstract}
The Reliability Analysis of a Prestressed Concrete Beam (PCB) was presented using First Order Reliability Method and Euro code 2 procedures to carry out the analysis. The results show that the safety of the PCB in bending decreased from 2.9 to 1.0 and 3.1 to 2.6 as prestress force and the depth from the extreme compressive fiber to the neutral axis of the beam increased from $20 \mathrm{kN}$ to $100 \mathrm{kN}$ and $150 \mathrm{~mm}$ to $350 \mathrm{~mm}$ respectively, therefore the PCB is safer at low prestress force and depth to the bottom layer of the beam. Also, the target safety indices considering bending criteria of the prestressed beam was obtained to be 2.01
\end{abstract}

Key word: Reliability analysis, Pre stressing, Reinforced Concrete Beam, Simply supported beam, Bending, Euro codes.

\subsection{INTRODUCTION.}

Prestressed concrete beam is mostly used for the construction of bridge projects worldwide. It can be used in many structural applications such as buildings, bridge girders, nuclear power vessels, offshore drilling platform and television towers [1](Antonie and Naaman 2004)

Prestressing is the process of inducing compressive stress zone of a structural element which may become tension under external loads. The introduction of compressive stress in the structural element helps to neutralize the tensile stress that might occur so that no resultant tension exists.

This implies that cracking is eliminated in the structural element under working load and all of the concrete may be assumed effective in carrying load. Therefore, lighter sections may be used to carry a given bending moment and over much longer spans than reinforced concrete.

High tensile steel is used to produce the prestressing force and high quality concrete is used to resist the higher compressive stress that are developed [2](Mosley and Bungey, 2002). In the design and construction of the prestressed concrete, there are many source of uncertainties which are put into consideration during the construction in order for the structure to serve its intended purpose. Consequently, structures must be designed to serve their functions with a finite probability of failures [3](Nowak and Colins, 2002).

Reliability analysis is used to eliminate these uncertainties in the construction processes of the pestressed concrete. Reliability is the probability that the structure will perform its required function without failure under a specified limit state during a specified reference period [4](Thoft- Christensen and Baker, 1982). The probability of structural failure from all possible causes is inevitable. However, the uncertainties and their significance on the structural safety and performance can be analyzed systematically only through methods of probability.

The development of structural reliability methods during the last three to four decades have provided a more rational basis for the design of structures in the sense that the method facilitates a consistent basis of comparison between the reliability of a well-tested structural design and the reliability of new types of structures. As a result of this, structural reliability is now widely used in connection with the development of new design codes [5](Srenson et,al., 2002, Kim et,al. 2013).

The way in which civil engineering systems fail, the occurrence and frequency of failure, its economics and social consequences, indicates considerable differences between hypothetical and actual systems. Induced loading, site characterization, material 
properties, developed formulations and procedures and adequacy of predicted sizes and shapes of the system and its elements are far from certain. Reliability analysis of structures is required as a result of these problems.

This study is aimed at analyzing a simply supported prestressed concrete beam using reliability analysis method with the aid of First Order Reliability Method (FORM) and [6]Euro code2 (2004) design procedure. The following procedures was carried out to achieve the aim of this research: identification of the modes of failure, computation of the probability of failure associated with bending moment of the prestress concrete, determination of the implied safety indices related to the probability of failure, computation of the mean safety index for the mode of failure due to bending moment and establishment of a target safety index.

\subsection{METHODOLOGY}

The self-weight of a beam is the most typical load encountered in an unloaded simply supported beam design. As a result of this, the self-weight is the only load that is discussed in this research. The third level approach under the reliability method namely Monte Carlo simulation was conducted utilizing computer software FORM 5 to pick random variables from a specified probability distribution and the probability of failure was estimated. The limit state function for the prestressed concrete beam was derived using [6]Eurocode 2 (2004).

The rectangular prestressed concrete beam has a single tendon with breath (b), depth (d), and span (L). the parameters are shown in the table below. The prestressed beam was analyzed using [6]Euro code 2 (2004) procedures

The failure due to the bending occurs when the strength of the beam moment is less than or equal to the design bending moment strength i.e

$\phi \mathrm{Mu} \leq \mathrm{M}^{*}$

Where $\mathrm{Mu}=\sigma \mathrm{puAp}\left(\mathrm{dp}-\frac{\gamma d_{n}}{2}\right)+\operatorname{fyAst}\left(\operatorname{do}-\frac{\gamma d_{n}}{2}\right)$

$\mathrm{M}^{*}=\frac{w l^{2}}{8}$

$\mathrm{W}=1.35 \mathrm{GK}+1.5 \mathrm{Qk}+\gamma_{p} \mathrm{p}$

In equation (1) to (4)

MU and $\mathrm{M}^{*}$ are ultimate bending moment and applied bending moment respectively, $\sigma$ puis the stress in the prestressing steel,Ap and Ast are area of prestressed steel and area of reinforcement steel respectively.dp, do, and dn are depth to prestressed steel, depth to the bottom layer of tensile reinforcement and depth from the extreme compressive fiber to the neutral axis respectively.fy is yield stress of non-prestressed steel, w is the uniformly distributed load on the beam. Gk, Qk and P are dead load, imposed load and prestressing force respectively and $\gamma_{p}$ is an environmental constant.

It can be taken as $\gamma_{p}$,fav $=0.9$ when beneficial

or $\gamma_{p}$ unfav $=1.1$ when unfavourable.

Dividing equation (4) through by $\mathrm{Q}_{\mathrm{K}}$

Let $\mathrm{a}=\frac{G_{k}}{Q_{K}}(5)$

$\mathrm{W}=\mathrm{Q}_{\mathrm{k}}(1.35 \mathrm{a}+1.5)+\gamma_{p} \mathrm{p}$

Therefore $\mathrm{M}^{*}=\frac{Q_{k}(1.35 a+1.5)+\gamma_{p} \mathrm{p}}{8}$

The condition for failure is given as;

$\mathrm{G}(\mathrm{X})=\mathrm{Mu}-\mathrm{M}^{*} \leq 0$

The safety margin is given by:

$\mathrm{G}(\mathrm{X})=\left(\sigma \mathrm{puAp}\left(\mathrm{dp}-\frac{\gamma d_{n}}{2}\right)+\operatorname{fyAst}\left(\mathrm{do}-\frac{\gamma d_{n}}{2}\right)\right)-\left(\frac{Q_{k}(1.35 a+1.5)+\gamma_{p} \mathrm{p}}{8}\right) \leq 0$ 
International Journal of Advances in Sientific Research and Engineering (ijasre), Vol 6 (10), October -2020

Table1. Parameters of Stochastic Model for Bending Moment

\begin{tabular}{|l|c|l|l|l|l|l|}
\hline S/N & Variables & $\begin{array}{l}\text { Distribution } \\
\text { types }\end{array}$ & $\begin{array}{l}\text { Expected } \\
\text { values }\end{array}$ & units & $\begin{array}{l}\text { Coefficient of } \\
\text { variation }\end{array}$ & $\begin{array}{l}\text { Standard } \\
\text { deviation }\end{array}$ \\
\hline 1 & $f_{c}^{\prime}$ & Log-normal & 35 & $\mathrm{~N} / \mathrm{mm}^{2}$ & 0.15 & 5.25 \\
\hline 2 & $\mathrm{~b}$ & Log-normal & 350 & $\mathrm{~mm}$ & 0.01 & 3.5 \\
\hline 3 & $\mathrm{~d}_{\mathrm{n}}$ & Normal & 239 & $\mathrm{~mm}$ & 0.01 & 2.39 \\
\hline 4 & $\gamma$ & Gamma & 1.15 & - & 0.3 & 0.345 \\
\hline 5 & $\mathrm{~d}_{0}$ & Normal & 690 & $\mathrm{Mm}$ & 0.01 & 6.9 \\
\hline 6 & $f_{y}$ & Log-normal & 410 & $\mathrm{~N} / \mathrm{mm}^{2}$ & 0.15 & 61.5 \\
\hline 7 & $\mathrm{~A}_{\mathrm{sc}}$ & Log-normal & 820 & $\mathrm{~mm}^{2}$ & 0.15 & 123 \\
\hline 8 & $\mathrm{~d}_{\mathrm{c}}$ & Normal & 60 & $\mathrm{~mm}^{2}$ & 0.01 & 0.6 \\
\hline 9 & $\sigma_{p u}$ & Log-normal & 70 & $\mathrm{~N} / \mathrm{mm}^{2}$ & 0.15 & 10.5 \\
\hline 10 & $\mathrm{~A}_{\mathrm{p}}$ & Log-normal & 1200 & $\mathrm{~mm} \mathrm{~m}^{2}$ & 0.15 & 180 \\
\hline 11 & $\mathrm{~d}_{\mathrm{p}}$ & Normal & 650 & $\mathrm{~mm}$ & 0.01 & 97.5 \\
\hline 12 & $\mathrm{Q}_{\mathrm{k}}$ & Gumbel & 5 & $\mathrm{KN} / \mathrm{m}^{2}$ & 0.3 & 1.5 \\
\hline 13 & $\mathrm{a}_{0}$ & Gamma & 1.5 & - & 0.3 & 0.45 \\
\hline 14 & $\gamma$ & Gamma & 0.9 & - & 0.3 & 0.27 \\
\hline 15 & $\mathrm{P}$ & Log-normal & 100 & $\mathrm{KN}$ & 0.15 & 150 \\
\hline 16 & $\mathrm{~L}$ & Normal & 10000 & $\mathrm{Mm}$ & 0.01 & 100 \\
\hline
\end{tabular}

\subsection{RESULTS AND DISCUSSIONS}

The results were obtained using FORM [7](Gowittzeret,al., 1988) and using the limit state functions derived in above. The derived limit state functions were derived considering the Eurocode 2 failure criteria of prestressed concrete beam. The parameters in table1 were also used for the analysis.

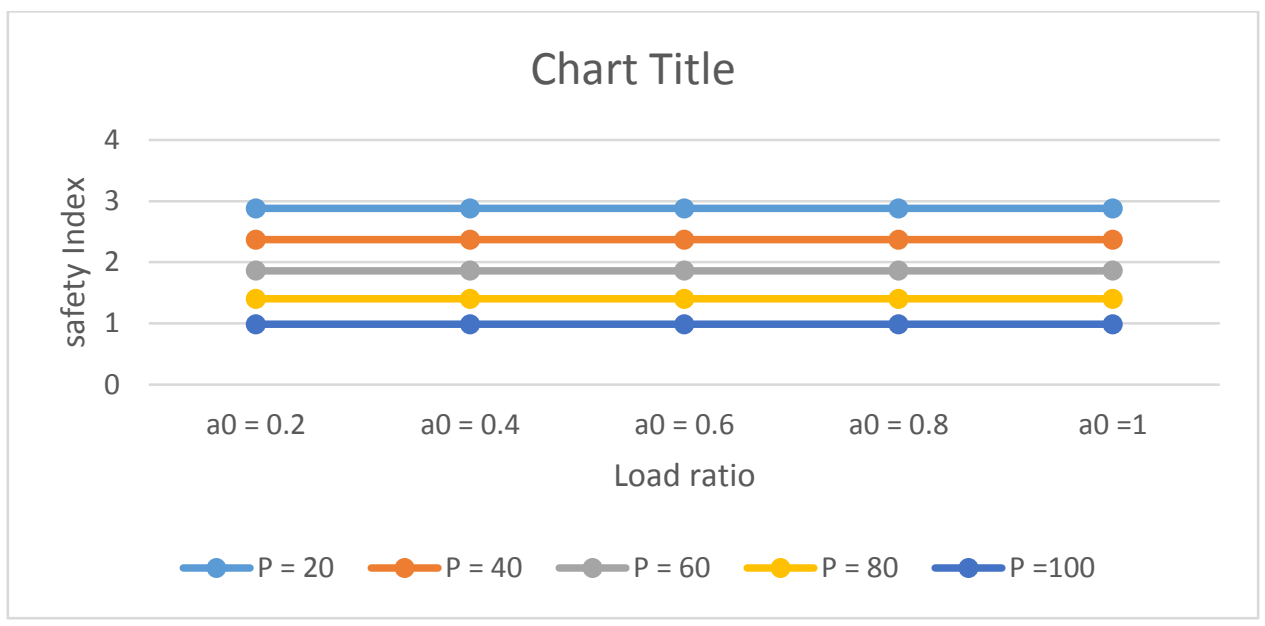

Fig 1. Variation of safety index with load and prestressing force

The graph above shows that $\mathrm{s}$ the load ratio increased the safety index remained constant. This indicates that the load ratio does not have effect on failure due to bending of the beam. This is because of the compressive force that was induced in the concrete which neutralizes all the tensile stress in the beam and made the concrete effective in carrying load [2](Mosley and Bungey, 2007). 


\section{Chart Title}

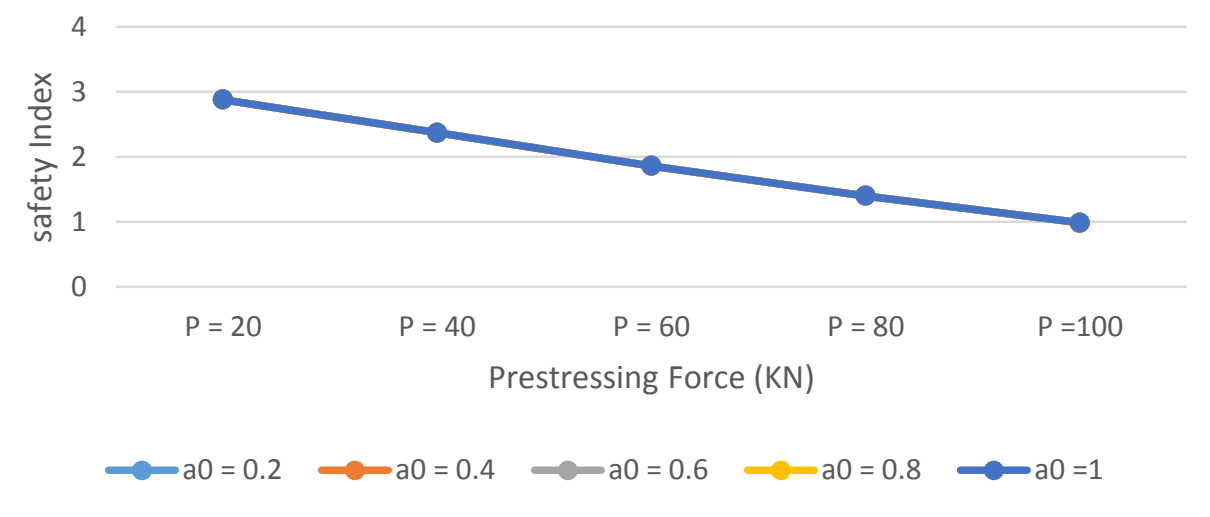

Fig. 2 Variation of safety index with prestressing force and load ratio.

Fig. 2 shows that as the prestress force increased the safety index decreased. Despite the safety index decreased as the prestress force increased the beam is still reliable when the value of the prestress force is within $80 \mathrm{KN}$ and $100 \mathrm{KN}$. Within this range of prestress force the safety index is within 1.5 and 1 respectively, which is safe and economical.

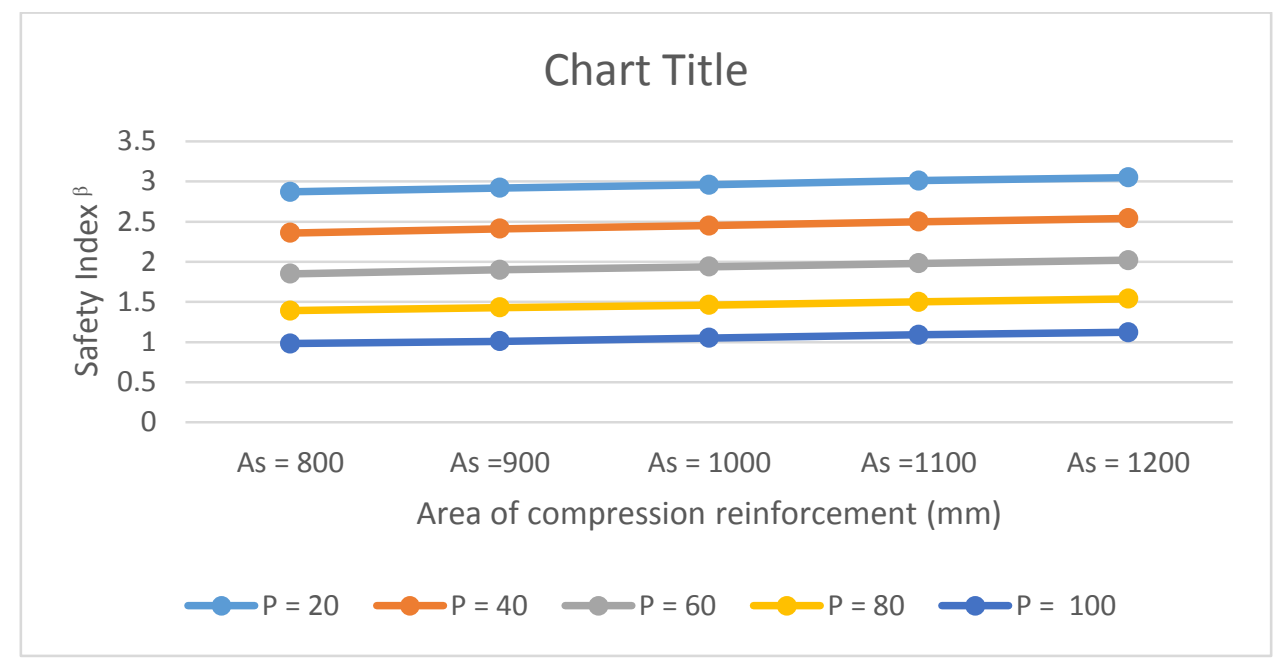

Fig. 3: Variation of safety index with area of compression reinforcement and pre stressing force.

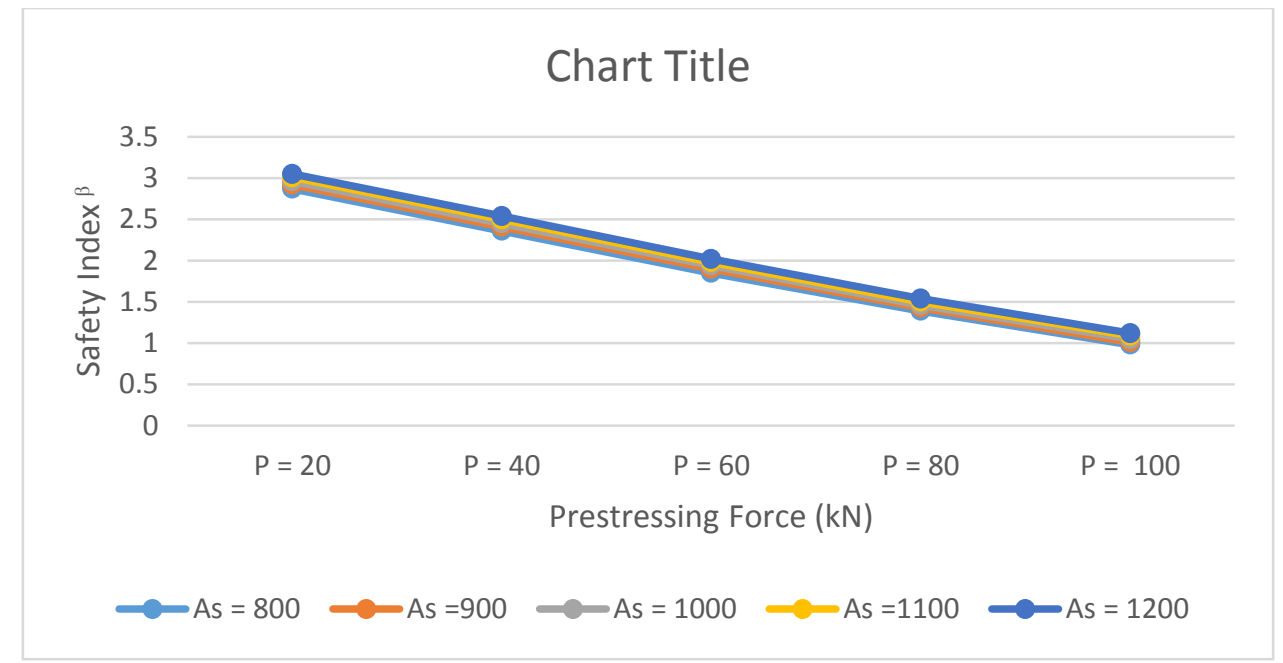

Fig.4: Variation of safety index with prestressing force and area of compression reinforcement. 
The effect of the variation of compressive reinforcement and prestresing force shown in Fig. 3 and Fig. 4 indicates that as the area of the compressive reinforcement increased in Fig.3, the safety index increased too. Thus the beam is safe with an increase in compressive reinforcement. While on the other hand the safety index decreases as the prestressing force increases.

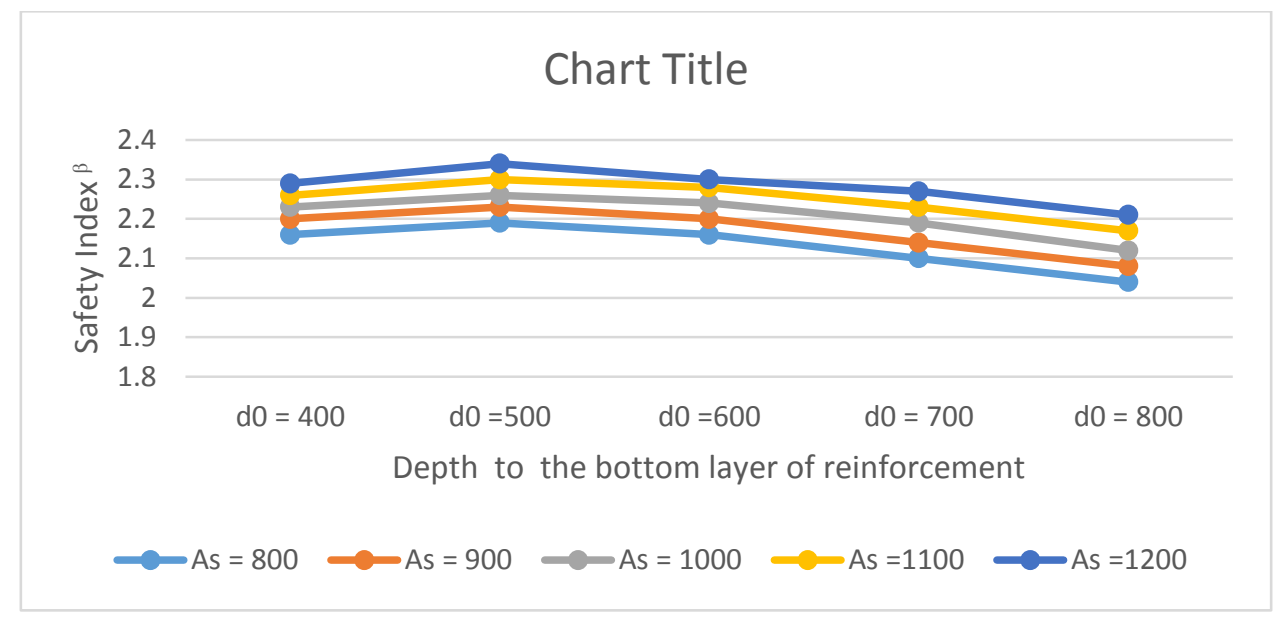

Fig 5: Variation of safety index with depth to the bottom layer of tensile reinforcement and are of compression reinforcement

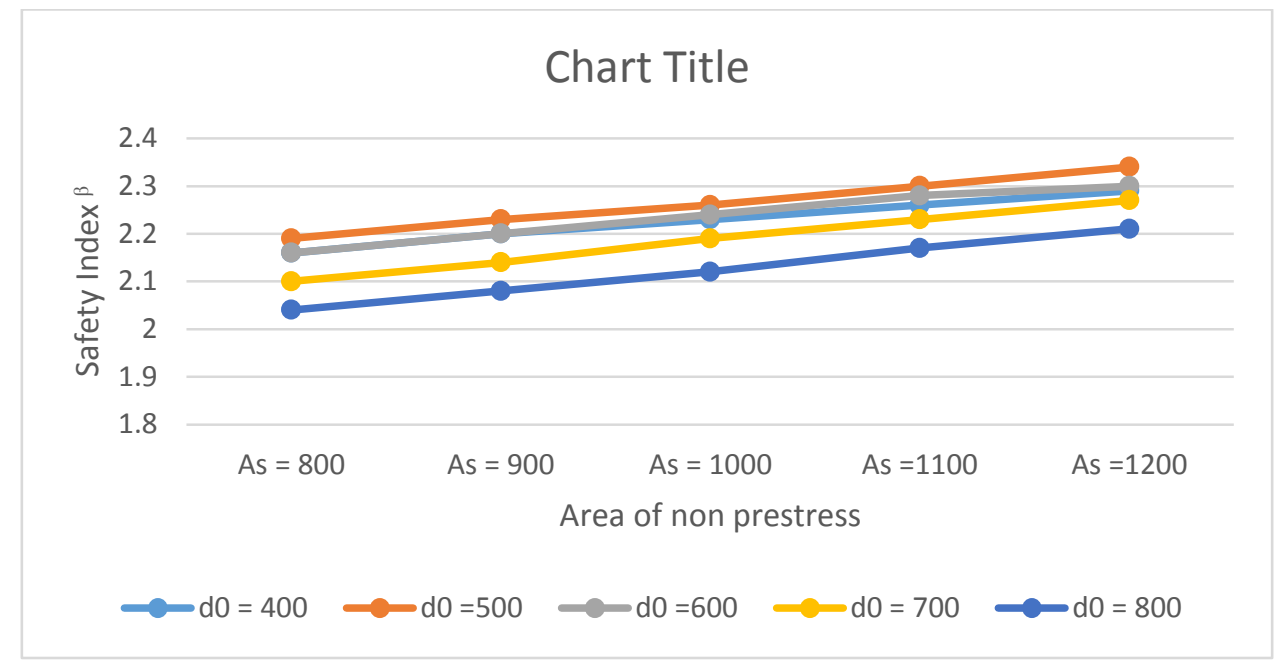

Fig. 6 Variation of Safety Index with area of compression reinforcement and depth to the tensile reinforcement.

The effect of the depth to the bottom layer of tensile reinforcement and compressive reinforcement are show in Fig.5 and Fig. 6. Fig. 5 shows that as the depth to the bottom layer increases the safety index reduces. The maximum safety index occurs when the depth is at $500 \mathrm{~m}$. at this point the safety index varies from 2.19 to 2.34 with the varied area of compressive reinforcement from $800 \mathrm{~mm}^{2}$ to $1200 \mathrm{~mm}^{2}$ respectively. While on the other hand as the area of compressive reinforcement increases the safety index increases. 


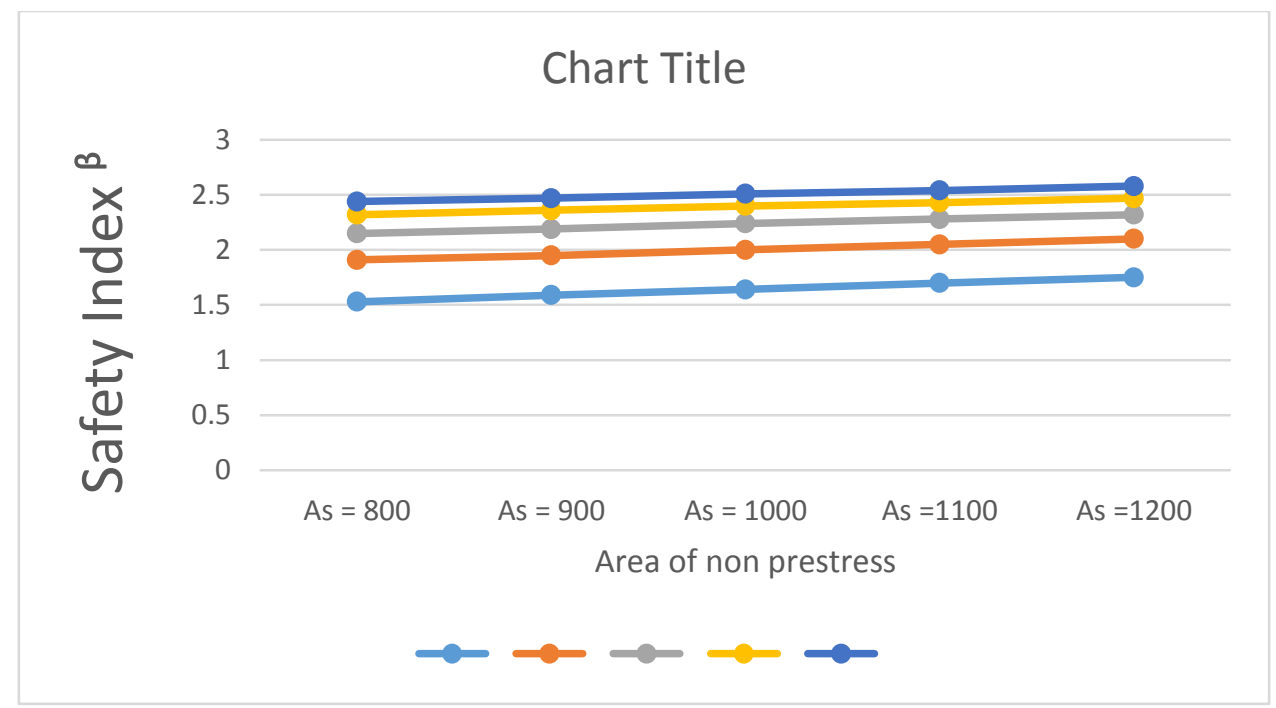

Fig. 7: variation of safety Index against Area of compression reinforcement with depth to neutral axis

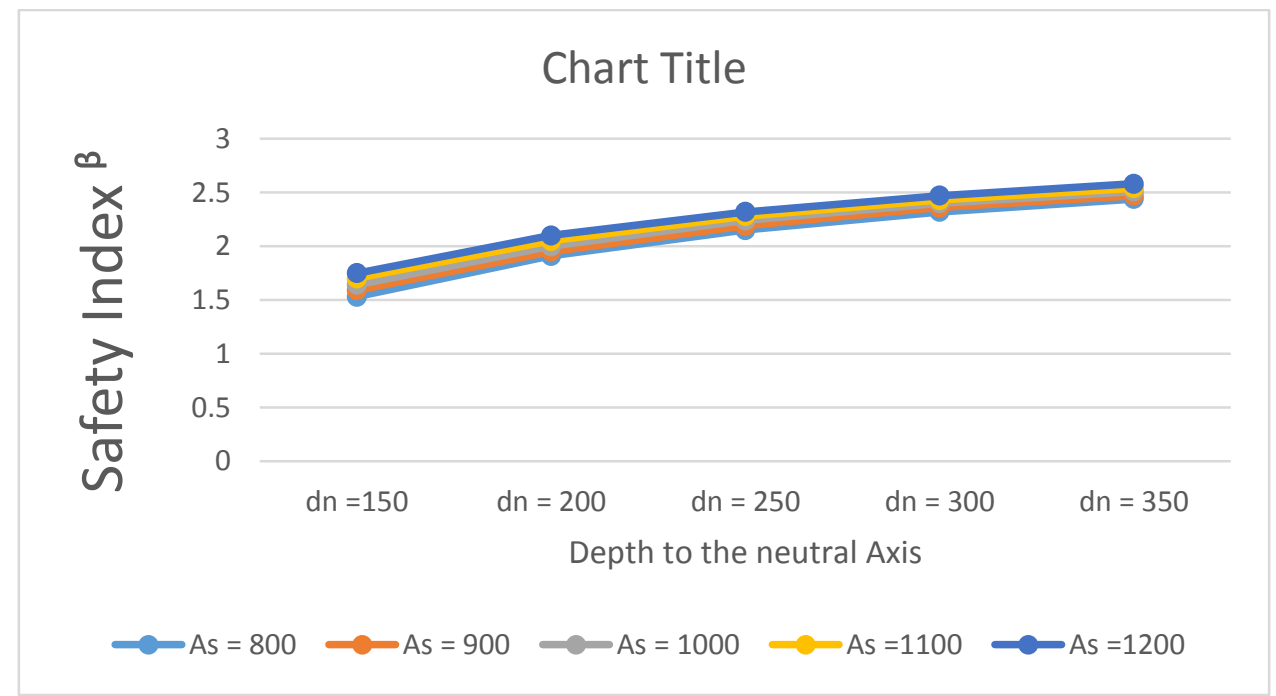

Fig. 8: Variation of Safety Index against Depth from extreme compressive fibre to the neutral axis

The effect of the variation of area of compressive reinforcement with depth from extreme compressive fiber to the neutral axis is shown in Fig. 7 and Fig. 8. The figures show that as both the area of the compressive reinforcement and the depth from extreme compressive fiber to the neutral axis increases the safety index increases. This means that at the increase of the both variables the beam is saved from failure due to bending. This is the because the compressive reinforcement provides the cracked concrete beam with flexural strength [8](Gilbert and Mickleborough, 1990). While the depth from the extreme compressive fiber to the neutral axis increases the safety through rigidity. 


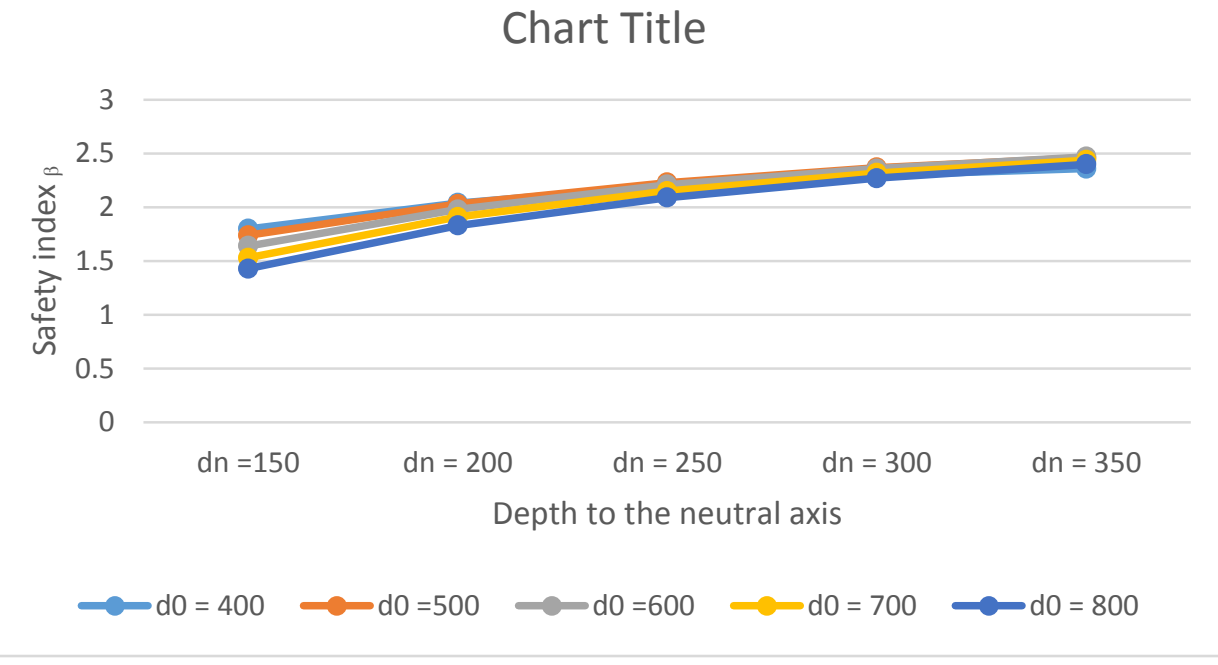

Fig.9: Variation of Safety index against depth to the neutral axis with depth to the bottom layer of tensile reinforcement

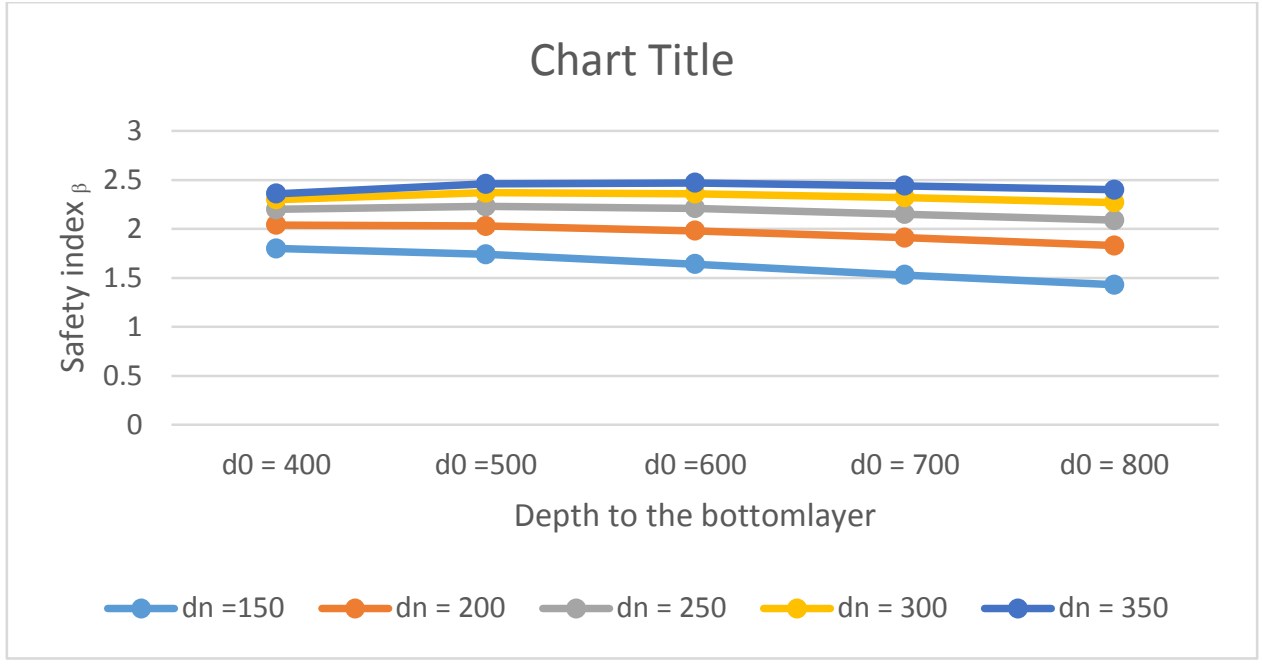

Fig. 10: Variation of safety index against depth to bottom layer of tensile reinforcement with depth from extreme compressive fiber to the neutral axis.

The effect variation of depth to the bottom layer of tensile reinforcement and depth to the extreme compressive fiber to the neutral axis is shown in Fig. 9 and Fig. 10. The figures show that as the depth to the bottom layer of tensile reinforcement increases the safety index increases. This means that the beam is saved with increased in depth to the bottom layer of tensile reinforcement. While on the other hand the safety index decreases with increases in depth to the extreme compressive fiber to the neutral axis indicating that the beam is not saved with increased in the depth to the extreme compressive fiber to the neutral axis.

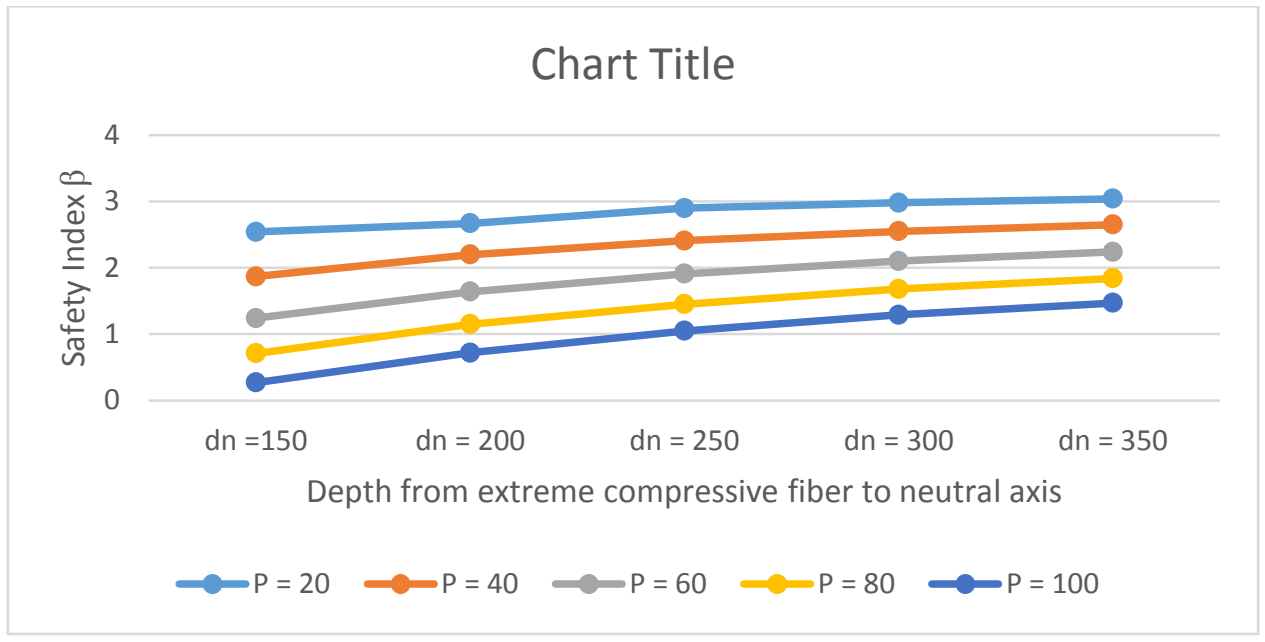

Fig. 11: Variation of safety index against depth from the extreme compressive fiber to neutral axis with prestress force 


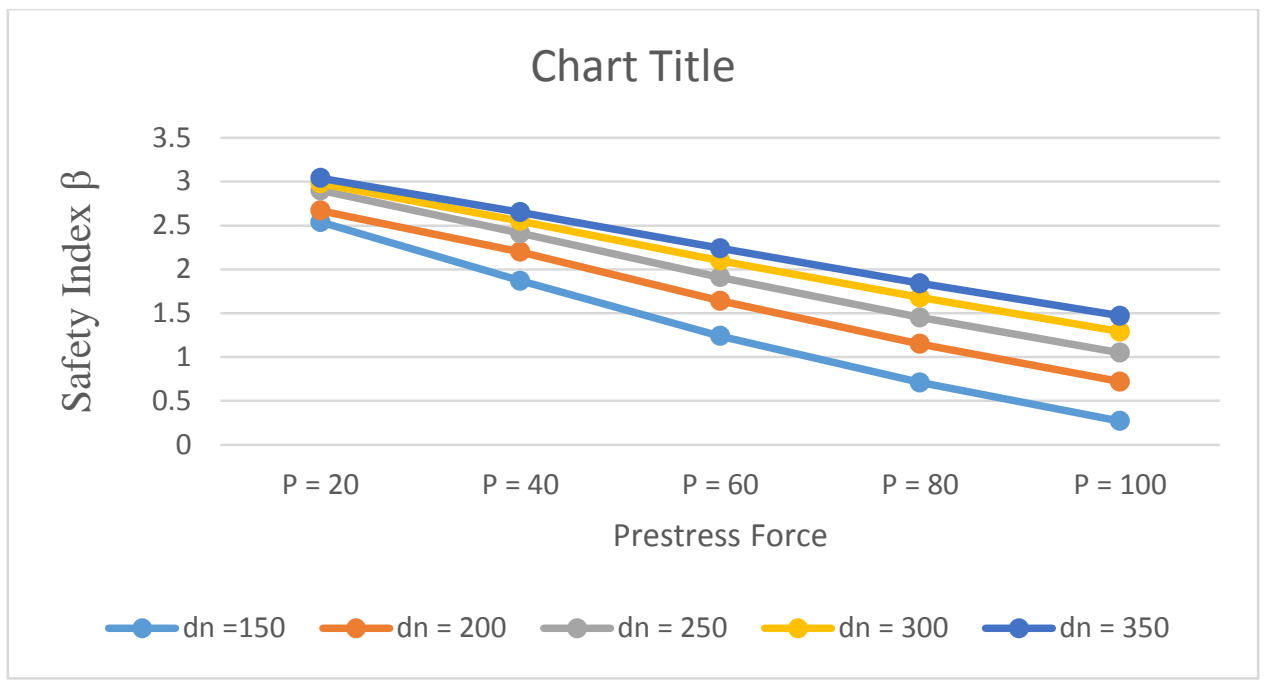

Fig. 12: Variation of safety index against prestressing force with depth from extreme compressive fiber to the neutral axis.

The effect of the variation of the prestress force and the depth from the compressive fiber to the neutral axis is shown in Fig 11 and Fig. 12. Fig. 11 shows that as the prestressing force increases the safety index reduces. This means that at increasing prestress force the beam tend to fail by bending while on the other hand Fig. 12 shows that as the depth from the compressive fiber to the neutral axis increases the safety index increases this means that at increased depth from compressive fiber to the neutral axis the beam is saved from failure due to bending. This implies that the greater the thickness of the beam, the more rigid and reliable the beam tend to be.

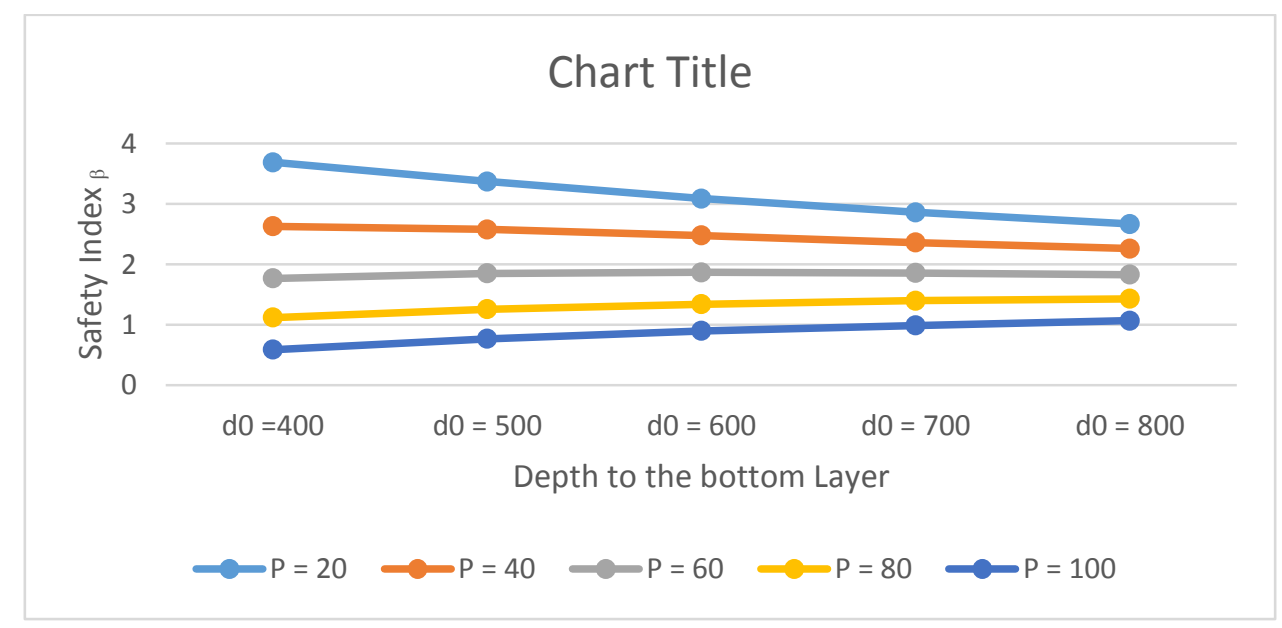

Fig. 13 Variation of depth to the bottom layer of tensile reinforcement with prestressing force

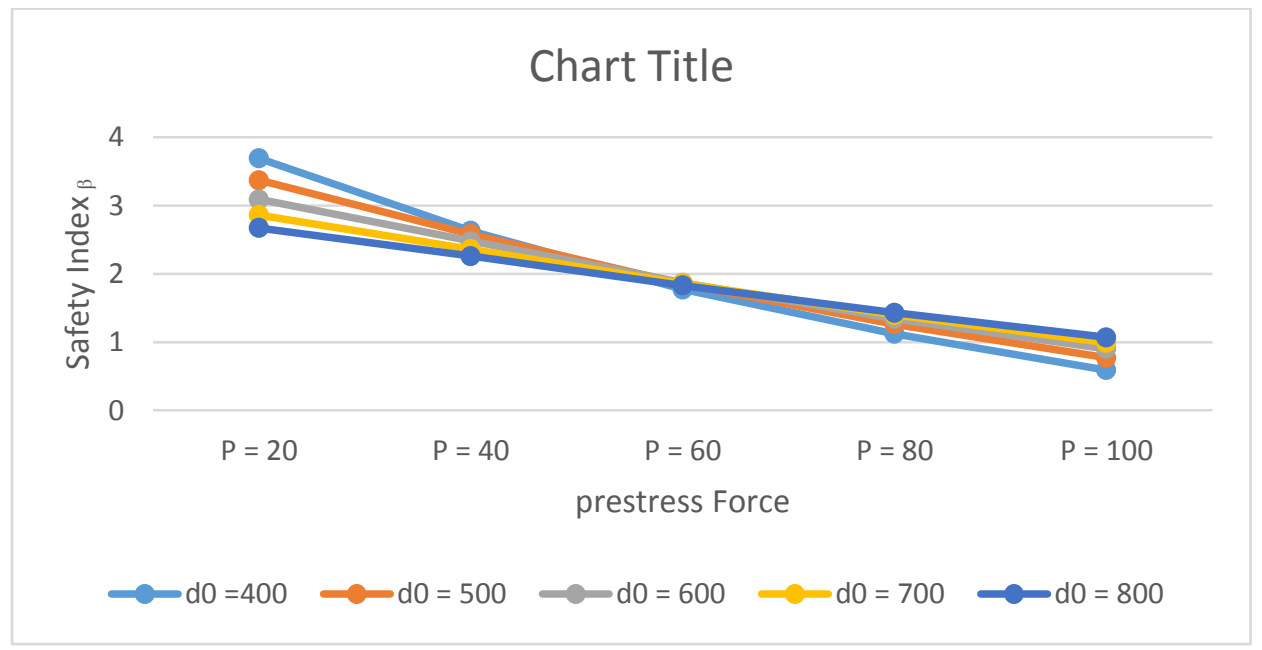

Fig. 14: Variation of safety index against prestressing force with depth to the bottom layer of tensile reinforcement. 
The effect of Variation of depth to the bottom layer of tensile reinforcement with prestressing force is in Fig. 13 and Fig. 14. Fig. 13 shows that as the depth to the bottom layer of tensile reinforcement increases the safety index tend to converge thereby it becomes constant meaning that the depth to the bottom layer of tensile reinforcement will not have effect on the failure due to bending as it increases. While Fig.14 shows that as the prestress force increases the safety index decreases. It also shows that when prestress force is $60 \mathrm{KN}$ the safety of the beam is at equilibrium. That is at $60 \mathrm{KN}$ the safety index for all depth is 1.83 which is safe and economical.

3.1 Reliability- based Design (considering Failure due to Bending Moment)

Parameters for the design of the beam are obtained from the graphs as follow:

From Fig. $2 \mathrm{P}=37 \mathrm{KN}, \mathrm{d}_{\mathrm{n}}=150 \mathrm{~mm}$

From Fig. $5 \mathrm{~d}_{\mathrm{n}}=200 \mathrm{~mm}, \mathrm{~A}_{\mathrm{sc}}=1100 \mathrm{~mm}^{2}$

From Fig. $10 d_{o}=500 \mathrm{~m}, d_{n}=200 \mathrm{~mm}$

(i) Prestress force and depth to the neutral axis

With prestress force of $37 \mathrm{KN}$ and depth from extreme compressive fiber to the neutral axis of $150 \mathrm{~mm}$ from Fig 2 the safety of the section is 2.0

(ii) Depth to the neutral axis and area of the compressive reinforcement with value of depth to the neutral axis of $200 \mathrm{~mm}$ and area of the compressive reinforcement of $1100 \mathrm{~mm}^{2}$ from Fig. 5 the safety of the beam is 2.0

(iii) Depth to the bottom layer of tensile reinforcement and depth to the neutral axis

With the value of depth to the bottom layer of tensile reinforcement of $500 \mathrm{~mm}$ and depth to the neutral axis of $200 \mathrm{~mm}$ from Fig. 10 the safety of the section is 2.0

\subsection{CONCLUSION AND RECOMMENDATION}

\subsection{Conclusion}

The safety of the prestressed concrete beam in bending decreases as prestress force and the depth to the bottom layer of the beam increases. It increases as depth to the neutral axis, area of the compressive reinforcement and eccentricity increases. Also the safety of the prestressed concrete beam remains constant in bending with increase in the effective width and load ratio of the beam.

\subsection{Recommendations}

Based on the outcome of the study and observations; it is recommended that that: The safety of prestressed concrete beam depends on bending condition as revealed in this study. Prestress force value should not exceed 100KN when prestressing a beam for bridge construction.

\section{REFEENCES}

[1] Antonie, E. Naman (2004) "Prestressed concrete Analysis and Design” University of Michigan

[2] Mosley, W.H and Bungey, J.H. (2002) "Reinforced Concrete Design”, 5th - edition, Macmillian Press Limited, London

[3] Nowak, A.S and Collins, K.R (2002) "Reliability of Structures” MC Graw Hill, Boston

[4] Thoft-Christensen P. and Baker, M.J.(1982) “ Structural Reliability Theory and its Application”. Berlin Springer-Verlag

[5] Sorensen, J.D and Faber, M.H. (2002), "Reliability code calibration”, paper for the joint committee on structural.

[6] EuroCode 2 (2004) "Design of concrete structures - Part 1-1: General rules and rules for buildings"

[7] Gollwitzer, S., Abdu, T. and Rackwitz, R. (1988): "First Order Reliability Method Manual, RCP-GMBH, Munchen 19 West Germany

[8] Gilbert, R.I and Mickleborugh, N.C (1990) “Design of Prestressed Concrete”1st Edition, university press Cambridge, Great Britain. 
International Journal of Advances in Sientific Research and Engineering (ijasre), Vol 6 (10), October -2020

\section{APPENDIX I}

Table1, Variation of safety index against prestress Force and Load ratio

\begin{tabular}{|l|l|l|l|l|l|}
\hline & $\mathrm{a}_{0}=0.2$ & $\mathrm{a}_{0}=0.4$ & $\mathrm{a}_{0}=0.6$ & $\mathrm{a}_{0}=0.8$ & $\mathrm{a}_{0}=1$ \\
\hline $\mathrm{P}=20$ & 2.88 & 2.88 & 2.88 & 2.88 & 2.88 \\
\hline $\mathrm{P}=40$ & 2.37 & 2.37 & 2.37 & 2.37 & 2.37 \\
\hline $\mathrm{P}=60$ & 1.86 & 1.86 & 1.86 & 1.86 & 1.86 \\
\hline $\mathrm{P}=80$ & 1.4 & 1.4 & 1.4 & 1.4 & 1.4 \\
\hline $\mathrm{P}=100$ & 0.986 & 0.986 & 0.986 & 0.986 & 0.986 \\
\hline
\end{tabular}

Table 2, Variation of Safety Index against prestress Force and Area of Steel Reinforcement

\begin{tabular}{|l|l|l|l|l|l|}
\hline & $\mathrm{A}_{\mathrm{s}}=800$ & $\mathrm{~A}_{\mathrm{s}}=900$ & $\mathrm{~A}_{\mathrm{s}}=1000$ & $\mathrm{~A}_{\mathrm{s}}=1100$ & $\mathrm{~A}_{\mathrm{s}}=1200$ \\
\hline $\mathrm{P}=20$ & 2.87 & 2.92 & 2.96 & 3.01 & 3.05 \\
\hline $\mathrm{P}=40$ & 2.36 & 2.41 & 2.45 & 2.5 & 2.54 \\
\hline $\mathrm{P}=60$ & 1.85 & 1.9 & 1.94 & 1.98 & 2.02 \\
\hline $\mathrm{P}=80$ & 1.39 & 1.43 & 1.46 & 1.5 & 1.54 \\
\hline $\mathrm{P}=100$ & 0.98 & 1.01 & 1.05 & 1.09 & 1.12 \\
\hline
\end{tabular}

Table 3, Variation of Safety Index against Area of Non-Prestressed and Depth to the bottom

\begin{tabular}{|l|l|l|l|l|l|}
\hline & $\mathrm{d}_{0}=400$ & $\mathrm{~d}_{0}=500$ & $\mathrm{~d}_{0}=600$ & $\mathrm{~d}_{0}=700$ & $\mathrm{~d}_{0}=800$ \\
\hline $\mathrm{A}_{\mathrm{s}}=800$ & 2.16 & 2.19 & 2.16 & 2.1 & 2.04 \\
\hline $\mathrm{A}_{\mathrm{s}}=900$ & 2.2 & 2.23 & 2.2 & 2.14 & 2.08 \\
\hline $\mathrm{A}_{\mathrm{s}}=1000$ & 2.23 & 2.26 & 2.24 & 2.19 & 2.12 \\
\hline $\mathrm{A}_{\mathrm{s}}=1100$ & 2.26 & 2.3 & 2.28 & 2.23 & 2.17 \\
\hline $\mathrm{A}_{\mathrm{s}}=1200$ & 2.29 & 2.34 & 2.3 & 2.27 & 2.21 \\
\hline
\end{tabular}

Table 4, Variation of safety Index against Area of Non-prestress and Depth to the Neutral Axis

\begin{tabular}{|l|l|l|l|l|l|}
\hline & $d_{n}=150$ & $d_{n}=200$ & $d_{n}=250$ & $d_{n}=300$ & $d_{n}=350$ \\
\hline $\mathrm{A}_{\mathrm{s}}=800$ & 1.53 & 1.91 & 2.15 & 2.32 & 2.44 \\
\hline $\mathrm{A}_{\mathrm{s}}=900$ & 1.59 & 1.95 & 1.19 & 2.36 & 2.47 \\
\hline $\mathrm{A}_{\mathrm{s}}=1000$ & 1.64 & 2 & 2.24 & 2.4 & 2.51 \\
\hline $\mathrm{A}_{\mathrm{s}}=1100$ & 1.7 & 2.05 & 2.28 & 2.43 & 2.54 \\
\hline $\mathrm{A}_{\mathrm{s}}=1200$ & 1.75 & 2.1 & 2.32 & 2.47 & 2.58 \\
\hline
\end{tabular}

Table 5, Variation of safety Index against Depth to the Bottom Layer and Depth to the Neutral Axis

\begin{tabular}{|l|l|l|l|l|l|}
\hline & $\mathrm{d}_{\mathrm{n}}=150$ & $\mathrm{~d}_{\mathrm{n}}=200$ & $\mathrm{~d}_{\mathrm{n}}=250$ & $\mathrm{~d}_{\mathrm{n}}=300$ & $\mathrm{~d}_{\mathrm{n}}=350$ \\
\hline $\mathrm{d}_{0}=400$ & 1.8 & 2.04 & 2.2 & 2.3 & 2.36 \\
\hline $\mathrm{d}_{0}=500$ & 1.74 & 2.03 & 2.23 & 2.37 & 2.46 \\
\hline $\mathrm{d}_{0}=600$ & 1.64 & 1.98 & 2.21 & 2.36 & 2.47 \\
\hline $\mathrm{d}_{0}=700$ & 1.53 & 1.91 & 2.15 & 2.32 & 2.44 \\
\hline $\mathrm{d}_{0}=800$ & 1.43 & 1.83 & 2.09 & 2.27 & 2.4 \\
\hline
\end{tabular}

Table 6, Variation of Safety Index against Prestress Force and Depth to the Neutral Axis

\begin{tabular}{|l|l|l|l|l|l|}
\hline & $d_{n}=150$ & $d_{n}=200$ & $d_{n}=250$ & $d_{n}=300$ & $d_{n}=350$ \\
\hline$P=20$ & 2.54 & 2.67 & 2.9 & 2.98 & 3.04 \\
\hline$P=40$ & 1.87 & 2.2 & 2.41 & 2.55 & 2.65 \\
\hline $\mathrm{P}=60$ & 1.24 & 1.64 & 1.91 & 2.1 & 2.24 \\
\hline $\mathrm{P}=80$ & 0.71 & 1.15 & 1.45 & 1.68 & 1.84 \\
\hline $\mathrm{P}=100$ & 0.27 & 0.72 & 1.05 & 1.29 & 1.47 \\
\hline
\end{tabular}


International Journal of Advances in Sientific Research and Engineering (ijasre), Vol 6 (10), October -2020

Table 7, Variation of safety Index against Prestress Force and Depth to the Bottom

\begin{tabular}{|l|l|l|l|l|l|}
\hline & $\mathrm{d}_{0}=400$ & $\mathrm{~d}_{0}=500$ & $\mathrm{~d}_{0}=600$ & $\mathrm{~d}_{0}=700$ & $\mathrm{~d}_{0}=800$ \\
\hline $\mathrm{P}=20$ & 3.69 & 3.37 & 3.09 & 2.86 & 2.67 \\
\hline $\mathrm{P}=40$ & 2.63 & 2.58 & 2.48 & 2.36 & 2.26 \\
\hline $\mathrm{P}=60$ & 1.77 & 1.85 & 1.87 & 1.86 & 1.83 \\
\hline $\mathrm{P}=80$ & 1.12 & 1.26 & 1.34 & 1.4 & 1.43 \\
\hline $\mathrm{P}=100$ & 0.59 & 0.77 & 0.9 & 0.99 & 1.07 \\
\hline
\end{tabular}

\section{Appendix II}

PROGAM MOS1

C RELIABILITY BASED DESIGN OF A REINFORCED CONCRETE PRESTRESSED BEAM

C Considering bending and shear

C $\quad \mathrm{x}(1)=$ characteristic compressive strength

C $\quad x(2)=$ width of compressive zone

C $\quad \mathrm{x}(3)=$ ratio of the depth of the idealized rectang. Compre. Stress

C $\quad \mathrm{x}(4)=$ depth from the extreme compressive fiber to the neutral axis

C $\quad \mathrm{x}(5)=$ depth to the bottom layer of tensile reinforcement

C $\quad x(6)=$ yield stress of non prestress steel

C $\quad x(7)=$ area of compressive reinforcement

C $\quad x(8)=$ depth to the top layer of non prestress steel

C $\quad x(9)=$ Ultimate strength of the prestress steel

C $\quad \mathrm{x}(10)=$ area of prestress steel

C $\quad \mathrm{x}(11)=$ depth to the prestress steel

C $\quad x(12)=$ imposed load

C $\quad x(13)=$ ratio of the dead load to the live load

C $\quad \mathrm{x}(14)=$ environmental constant

$\mathrm{C} \quad \mathrm{x}(15)=$ prestress force

C $\quad x(16)=\operatorname{span}$

IMPLICIT DOUBLE PRECISION (A-H, O-Z)

C THE SUBROUTINE WITH THE LIMIT STETE FUNCTION IS

C DECLARED EXTERNAL

EXTERNAL GBEND

DIMENSION X (I6), EX (16), SX(16), VP (10, 16), COV(16, 16), ZES(3)

$+$

UU(16), EIVEC(16, 16), IV $(2,16)$

CHARACTER *10 PRT

$\mathrm{C}$

common/cbend/load 
International Journal of Advances in Sientific Research and Engineering (ijasre), Vol 6 (10), October -2020

DATA EX / 3.5D1, 3.5D2, 1.15D0, 2.39D2, 6.9D2, 4.1D2, 8.2D2, 6.0D1, 1.77D3,

$+\quad \quad 1.2 \mathrm{D} 3,6.5 \mathrm{D} 2,5.0 \mathrm{D}-3,6 . \mathrm{D}-1,9.0 \mathrm{D}-1,1.0 \mathrm{D} 5,1.0 \mathrm{D} 4 /$,

$+\quad \mathrm{SX} / 5.25 \mathrm{D} 0,3.5 \mathrm{D} 0,3.45 \mathrm{D}-1,2.39 \mathrm{D} 0,6.9 \mathrm{D} 0,6.15 \mathrm{D} 1,1.5 \mathrm{D} 2,6.0 \mathrm{D}-1$,

$+\quad 2.655 \mathrm{D} 2,1.8 \mathrm{D} 2,9.75 \mathrm{D} 1,1.5 \mathrm{D}-3,2.7 \mathrm{D}-1,2.7 \mathrm{D} 1,1.5 \mathrm{D} 4,1.0 \mathrm{D} 2 /$,

$+\quad \mathrm{N} / 16 /, \mathrm{NC} / 16 /, \mathrm{NE} / 16 /, \mathrm{IRHO} / 1 /$

WRITE $(*, *)$ 'ENTER DEPTH TO NEUTRAL AXIS dn....’’

$\operatorname{READ}(*, *) \operatorname{EX}(4)$

WRITE $(*, *)$ ‘ ENTER DEPTH TO BOTTOM OF PRESTRESS STEEL d0...>’

$\operatorname{READ}(*, *) \operatorname{EX}(5)$

WRITE $(*, *)$ 'ENTER AREAOF COMPRESSIVE REINFORCEMENT AS....'

$\operatorname{READ}(*, *) \operatorname{EX}(7)$

WRITE $(*, *)$ 'ENTER LOAD RATIO a0...>’

$\operatorname{READ}(*, *) \operatorname{EX}(13)$

WRITE(*,*) 'ENTER PRESTRESS FORCE P....’

$\operatorname{READ}(*, *) \operatorname{EX}(15)$

$\operatorname{SX}(4)=0.01 * \operatorname{EX}(4)$

$\mathrm{SX}(5)=0.01 * \operatorname{EX}(5)$

$\operatorname{SX}(7)=0.15^{*} \operatorname{EX}(7)$

$\operatorname{SX}(13)=0.3 * \operatorname{EX}(13)$

$\mathrm{SX}(15)=0.15 * \operatorname{EX}(15)$

THE RESULTS ARE WRITTEN TO NAUS 7

NAUS $=7$

PRINT TO SCREEN

$\mathrm{ICRT}=0$

$\operatorname{OPEN}(7$, FILE $=$ hadiz1. RES', STATUS $=$ 'OLD', ERR $=10)$

GOTO 20

$10 \operatorname{OPEN}(7$, FILE $=$ 'hadiz1. RES', STATUS $=$ 'NEW' $)$

C PRESETTING VARIABLES VP, COV, AND IV IS DONEUSING YINT

20 CALL YINT (N, IV,VP, IRHO, COV, NC)

IV $(1,1)=3$

$\operatorname{IV}(1,2)=3$

$\operatorname{IV}(1,4)=5$

$\operatorname{IV}(1,6)=3$

$\operatorname{IV}(1,7)=3$ 
International Journal of Advances in Sientific Research and Engineering (ijasre), Vol 6 (10), October -2020

$$
\begin{aligned}
& \operatorname{IV}(1,9)=3 \\
& \operatorname{IV}(1,12)=5 \\
& \operatorname{IV}(1,13)=7
\end{aligned}
$$

IV $(1,14)=3$

DO $100 \mathrm{I}=1, \mathrm{~N}$

$100 \quad \mathrm{X}(\mathrm{I})=\mathrm{EX}(\mathrm{I})$

$\mathrm{V} 1=1.0$

$\mathrm{BETA}=1 . \mathrm{D} 0$

C INITIAL SOLUTION ESTIMATE

WRITE (NAUS, 5000)

5000 FORMAT (IIII, 5X, 70 ('*'), /, 30X, 'FORM 5', /, 5X, 70('*’), /,

+ 'ECCENTRICALLY LOADED CONNECTION OF STEEL, 16 VARIABLES:')

CALL YKOPF (NAUS, N, IV, EX, SX, VP, IRHO)

WRITE (ICRT, *) 'START OF FORM 5'

WRITE (ICRT, *) 'STOCHASTIC MODEL:'

CALL YKOPF (ICRT, N, IV, EX, SX, VP, IRHO)

$\mathrm{PRT}={ }^{`} \mathrm{COV}$ '

CALL YMAUS (NAUS, NC, N, COV, PRT)

CALL FORM5 (N, IV, EX, SX, VP, GBEND, IRHO, COV, NC,

$+$ EIVEC, NE, V1, NAUS, BETA, X, UU, ZES, IER)

C THE CORDINATE OF THE BETA POINT ARE PRINTED WITH THE

C THE TITLE VECTOR UU

$\mathrm{PRT}=$ 'UU'

CALL YFAUS (NAUS, 3, ZES, PRT)

WRITE (ICRT，*) 'END OF FORM5 : IER = ‘, IER

WRITE (ICRT, *) 'RESULTS SEE FILE hadiz1. RES'

STOP

END

SUBROUTINE GBEND (N, X,FX, IER)

IMPLICIT DOUBLE PRECISION (A-H, O-Z)

DIMENSION X(N)

C common/cbend/load

$$
\begin{aligned}
& \mathrm{A}=(\mathrm{X}(5)-\mathrm{X}(4) / 2) \\
& \mathrm{B}=0.85 * \mathrm{X}(1) * \mathrm{X}(2) * \mathrm{X}(3) * \mathrm{X}(4) * \mathrm{~A} \\
& \mathrm{C}=\mathrm{X}(6) * \mathrm{X}(7) *(\mathrm{X}(5)-\mathrm{X}(8))
\end{aligned}
$$


International Journal of Advances in Sientific Research and Engineering (ijasre), Vol 6 (10), October -2020

$$
\begin{aligned}
\mathrm{D}=0.9 * \mathrm{X}(9) * \mathrm{X}(10) *(\mathrm{X}(5)-\mathrm{X}(11)) \\
\mathrm{FS}=\mathrm{B}+\mathrm{C}-\mathrm{D} \\
\mathrm{E}=(1.35 * \mathrm{X}(13)+1.5) \\
\mathrm{AG}=\mathrm{X}(12) * \mathrm{E} \\
\mathrm{AH}=\mathrm{AG}+(\mathrm{X}(14) * \mathrm{X}(15)) \\
\mathrm{PT}=(\mathrm{AH} *(\mathrm{X}(16) * * 2)) / 8
\end{aligned}
$$

\section{CHECK FOR ERRORS}

IF (PT. GT. 0) THEN

$\mathrm{FX}=\mathrm{FS}-\mathrm{PT}$

IER $=0$

ELSE

$\mathrm{FX}=1 . \mathrm{D}+20$

IER $=1$

ENDIF

RETURN

END 